\title{
PEMANFAATAN KOLAM PENGENDAP TAMBANG BATUBARA UNTUK BUDIDAYA IKAN LOKAL DALAM KERAMBA
}

\author{
Asfie Maidie"), Deni Udayana"), Isriansyah"), Ismail Fahmy Almady"), \\ Adi Susanto"), Komsanah Sukarti"), Sulistiawaty"), Imanuel Manege ${ }^{* *}$, \\ dan Evie Tular*) \\ *) Fakultas Perikanan dan Ilmu Kelautan, Universitas Mulawarman \\ Kampus G. Kelua, Samarinda 75123 \\ E-mail: asfiemaidie@live.jp \\ ${ }^{* *)}$ PT Kaltim Prima Coal (KPC), Sengatta
}

(Naskah diterima: 9 Juli 2010; Disetujui publikasi: 10 Desember 2010)

\begin{abstract}
ABSTRAK
Uji coba budidaya dalam keramba telah dilakukan untuk mengetahui kelayakan kolam pengendap tambang batubara untuk areal budidaya ikan bagi masyarakat sekitar apabila kegiatan tambang telah ditutup, serta untuk mengetahui apakah produk ikan yang dihasilkan cukup aman untuk dikonsumsi manusia. Percobaan dilakukan pada bekas kolam pengendap DS2 milik PT KPC, dengan mengunakan 5 buah keramba apung berukuran $3 \mathrm{~m} \times 1 \mathrm{~m} \times 1 \mathrm{~m}$ yang dalam setiap keramba ditebar benih dari alam untuk ikan repang (Barbodes schwanenfeldii) ukuran rata-rata 20,2 g; puyau (Osteichilus kappenii) ukuran $66,1 \mathrm{~g}$; dan mas (Cyprinus carpio) ukuran 28,96 g dari pemijahan di laboratorium sebanyak masing-masing 200 ekor, serta pepuyu (Anabas testudineus) ukuran rata-rata 41,4 g dari alam sebanyak 50 ekor, udang galah (Macrobrachium rosenbergii) ukuran $113,8 \mathrm{~g}$ juga dari alam sebanyak 50 ekor. Pakan diberikan secara sampai kenyang (ad libitum). DO, pH, suhu, DHL, dan kekeruhan diukur harian, sedangkan ikan diukur pertumbuhan bobotnya. Setelah dipelihara selama 4 bulan dan memenuhi ukuran konsumsi, ikan dan udang diperiksa kandungan $\mathrm{Sb}, \mathrm{Se}, \mathrm{As}, \mathrm{Hg}$, $\mathrm{Mn}, \mathrm{Cd}, \mathrm{Fe}, \mathrm{Cu}, \mathrm{Pb}$, dan $\mathrm{Zn}$. Hasil penelitian menunjukkan bahwa bekas kolam pengendap tambang batubara cukup layak untuk dikembangkan sebagai areal budidaya ikan dengan memberikan pertumbuhan bobot populasi sebesar $570,79 \%$ (repang, SR: 95\%), 202,57\% (puyau, SR: 97\%), 573\% (mas, SR: 2,5\%), 238,92\% (udang galah, SR: 10\%), 447,10\% (pepuyu, SR: 14\%) dan produknya cukup aman untuk dikonsumsi, dengan kandungan $\mathrm{Sb}(0,24-2,45 \mathrm{mg} / \mathrm{L}$, rasio terdeteksi dari sample: $100 \%)$, Se $(0,00-0,06$, 57,14\%), As (tidak terdeteksi/ttd), $\mathrm{Hg}(0,00-0,06 \mathrm{mg} / \mathrm{L}, 50 \%), \mathrm{Mn}(\mathrm{ttd}-1,68 \mathrm{mg} / \mathrm{L}, 14,29 \%)$, $\mathrm{Cd}$ (ttd), Fe (ttd-5,45 mg/L, 7,14\%), Cu (ttd), Pb (ttd), dan Zn (7,82-61,50 mg/L, 100\%).
\end{abstract}

KATA KUNCl: kolam pengendap, keramba, ikan lokal, batubara, Kalimantan Timur

ABSTRACT: Utilization of Coal Mining Sedimentation Pond as a site for Endemic Fish Cage Culture. By: Asfie Maidie, Deni Udayana, Isriansyah, Ismail Fahmy Almady, Adi Susanto, Komsanah Sukarti, Sulistiawaty, Imanuel Manege, and Evie Tular

The experiment was conducted to study the feasibility of settling or sedimentation pond of coal mining to be used for culturing fish in net cage for local people post mining activities. Experimental $3 \mathrm{~m} \times 1 \mathrm{~m} \times 1 \mathrm{~m}$ of 5 floating net cages were located in DS 2, an abandoned settling pond owned by Kalimantan Timur Prima Coal (KPC). Each cage was stocked with natural barb seed (Barbodes schwanenfeldii) with 
mean weight of $20.2 \mathrm{~g}$, fresh water carp or puyau (Osteichilus kappenii) with mean weight of $66.1 \mathrm{~g}$, and common carp (Cyprinus carpio) with mean weight of $28.96 \mathrm{~g}$ from fish hatchery with density of 200 seeds per species per cage, wild seed of climbing pearch (Anabas testudineus) with mean weight of $41.4 \mathrm{~g}$ and density of 50 seeds per cage, and giant prawn (Macrobrachium rosenbergii) with mean weight $113.8 \mathrm{~g}$ and density of 50 seeds per cage. The fishes were feed ad libitum. Water quality parameters were measured daily consisting of $\mathrm{DO}, \mathrm{pH}$, temperature, conductivity, and turbidity, while fish growth was determined by measuring its weight. After 4 months of rearing and reached marketable size, the fish were then measured for the evidence of $\mathrm{Sb}, \mathrm{Se}, \mathrm{As}, \mathrm{Hg}, \mathrm{Mn}, \mathrm{Cd}, \mathrm{Fe}, \mathrm{Cu}, \mathrm{Pb}$, and $\mathrm{Zn}$. The result shows that the settlement pond of coal mining is feasible to rear fish in cage. The recorded fish growths were $570.79 \%$ for barb fish with survival rate/SR: $95 \%, 202.57 \%$ for local carp with SR: 97\%, 573\% for common carp with SR:2.5\%), 238.92\% for giant prawn with SR:10\%), $447.10 \%$ for climbing perch with SR:14\%. All of the reared fish are safe to be consumed because they have normal content of $\mathrm{Sb}(0.24$ to $2.45 \mathrm{mg} / \mathrm{L}$, and detected ratio in all sample was: $100 \%$ ), Se (0.00 to 0.06; $57.14 \%$ ), As (not detected/nd), $\mathrm{Hg}$ (0.00 to $0.06 \mathrm{mg} / \mathrm{L}, 50 \%$ ), $\mathrm{Mn}$ (nd to $1,68 \mathrm{mg} / \mathrm{L}, 14.29 \%$ ), Cd (nd), $\mathrm{Fe}$ (nd-5.45 mg/L, 7.14\%), $\mathrm{Cu}(\mathrm{nd}), \mathrm{Pb}(\mathrm{nd})$, and $\mathrm{Zn}(7.82-61.50 \mathrm{mg} / \mathrm{L}, 100 \%)$.

\section{KEYWORDS: sedimentation pond, fish cage, local fish, coal, East Kalimantan}

\section{PENDAHULUAN}

Penambangan batubara dengan sistem open pit berdasarkan Peraturan Pemerintah Indonesia dalam Permen ESDM No.18 memang seharusnya tidak menyisakan lobang galian setelah proyek berakhir. Tetapi kenyataan menunjukkan bahwa ini sulit untuk dipenuhi karena berarti harus menggali lagi tanah dan batuan di tempat lain untuk menutup lobang besar dan sangat dalam yang tersisa. Apalagi lobang bekas galian ini sering juga diminta oleh masyarakat lokal untuk penampungan air bagi keperluan pertanian dan rumah tangga, dan untuk usaha pembudidayaan ikan dalam keramba (fish cage).

Simmons et al. (2001) telah berhasil melakukan uji coba pembudidayaan ikan salmon di bekas kolam pengendap tambang batu bara. Percobaan ini dilakukan selain untuk menguji kelayakan kolam pengendap bagi usaha akuakultur, juga sebagai pembuka peluang kerja wilayah West Virginia yang memiliki banyak pengangguran. Sebelumnya Heinen (1996) telah menguji keamanan ikan hasil budidaya di kolam pengendap tambang batubara, dan diperoleh hasil bahwa produk ikan cukup aman untuk dikonsumsi manusia.

Sebagai satu jenis dari bentuk perairan umum atau inland waters, kolam pengendap tambang batubara juga harus memenuhi kriteria kuantitas dan kualitas air bagi pembudidayaan ikan. Kualitas air yang akan masuk di kolam pengendap tambang batu bara sangat dipengaruhi oleh sifat kimia dari lapisan batubara dan geologi lokal. Sifat utama dari lapisan batubara adalah kandungan besi dan sulfur atau pyrite, sedangkan sifat geologi lokal akan mempengaruhi kualitas air dengan masuknya aliran dari permukaan tanah yang membawa kikisan dan larutan mineral dalam alirannya (Miller et al., 2004), yang bersifat asam sehingga disebut limbah air asam tambang (acid mine drainage) yang merupakan hasil oksidasi mineral sulfide dari batuan dan tanah galian yang terekspose dengan atmosfer (Herrman \& Baumgratner, 1992; van Breemen, 1973). Pengaruh negatif penting dari air asam tambang terhadap kehidupan ikan adalah $\mathrm{pH}$ yang sangat rendah $(\mathrm{pH}<3,5)$ (Saiki et al., 1995; Short et al., 1990), walaupun air asam tambang dari senyawa sulfur (S) ini juga melarutkan logam aluminium (Al), besi (Fe), seng ( $\mathrm{Zn})$, manganese $(\mathrm{Mn})$, tembaga $(\mathrm{Cu})$, ataupun cadmium (Cd) ke perairan (Grippo \& Dunson, 1996), tetapi dampak logam-logam ini terhadap telur ikan dan yuwana ikan adalah minimal dibandingkan dengan pengaruh $\mathrm{pH}$ asam (Lachance et al., 2000; Fiss \& Carline, 1993; Ingersoll et al., 1990), apalagi sifat peracunan logam-logam ini seringkali bersinergis dengan keadaan dari ikan, seperti tingkat keracunan yang meningkat untuk logam cadmium $(C d)$ apabila ikan kekurangan selenium (Se) (AbdelTawwab \& Wafeek, 2010), ataupun pada ikanikan di masa yuwana yang hanya mengkonsumsi invertebrata jenis tertentu yang 
mengandung logam berat sehingga mempengaruhi fisiologis dan biokimia tubuh yang bisa berakibat kematian (Farag et al., 1999). Kelarutan logam-logam ini di media air tidak hanya mempengaruhi fisiologis dan biokimia dalam siklus hidup ikan, tetapi juga kandungan logam ini dalam daging atau bagian tubuh organisme ikan (Silva \& Shimizu, 2004) yang dipengaruhi oleh alkalinitas dan kesadahan perairan (Hanten et al., 1998), berhubungan dengan ukuran panjang atau bobot ikan itu sendiri (Salam et al., 2002), dengan umur ikan, jenis invertebrata yang dimakan, dan kedalaman perairan, tetapi berkorelasi negatif dengan kecepatan tumbuh, dan tak berkorelasi dengan jenis kelamin (Stafford et al., 2004), serta berhubungan dengan kebiasaan makan (feeding habit) dari ikan seperti sifat herbivora, karnivora ataupun omnivora. Ikan-ikan yang menduduki level tertinggi dalam piramid makanan berkecenderungan untuk memiliki kandungan logam yang tertinggi pula sebagai akibat bioakumulasi (Silva \& Shimizu, 2004). Selain daripada itu, konsentrasi logam berat di dalam tubuh ikan juga bervariasi berdasarkan musim (Gorski et al., 1999). Dampak peracunan logam, utamanya logam berat, biasanya akan berakibat kematian ataupun cacat pada ikan-ikan muda atau yuwana tetapi jarang pada ikan-ikan berukuran besar atau dewasa, sehingga masih dapat diharapkan pertumbuhan yang baik dari ikan budidaya. Apalagi dengan adanya usaha penambahan kapur untuk meningkatkan $\mathrm{pH}$, yang sekaligus juga akan meningkatkan alkalinitas dan kesadahan, dan dapat menurunkan kelarutan logam air raksa $(\mathrm{Hg})$, timah hitam $(\mathrm{Pb})$, ataupun tembaga (Cu) di kolom air (Goddard et al., 2008; McNevin \& Boyd, 2004; Hanten Jr. et al., 1998). Dalam hal ini, Pemerintah Daerah Kalimantan Timur melalui SK Gubernur Kalimantan Timur No. 26 Tahun 2002 telah menyaratkan parameter baku mutu limbah cair tambang batubara yang akan dialirkan ke badan air melewati kolam pengendap adalah sebagai berikut: total suspended solid (TSS) tidak melebihi 400 $\mathrm{mg} / \mathrm{L} ; \mathrm{pH}$ di antara 6,0 - 9,0; Fe tidak melebihi $10 \mathrm{mg} / \mathrm{L}$, dan $\mathrm{Mn}$ tidak melebihi $5 \mathrm{mg} / \mathrm{L}$. Kualitas air limbah seperti yang telah ditetapkan ini diharapkan tidak akan mengganggu dan mencemari ekosistem perairan umum. Tetapi dengan berdasarkan cara budidaya ikan yang baik (Keputusan Menteri Kelautan dan Perikanan Republik Indonesia No: KEP. 02/MEN/2007) yang menyaratkan tentang keamanan untuk dikonsumsi produk ikan yang dihasilkan, maka perlu dilakukan pengujian kandungan logam pada ikan dan udang yang dipelihara.

Apalagi hingga saat ini budidaya ikan di kolam-kolam bekas tambang batubara telah pula dilaksanakan masyarakat secara luas, tetapi belum ada tinjauan secara ilmiah tentang kelayakannya dalam menunjang kehidupan ikan budidaya, serta keamanan produk tersebut untuk dikonsumsi manusia, yang mendorong dilakukannya penelitian ini.

Tujuan dari penelitian ini adalah untuk mengetahui apakah kolam bekas tambang batubara cukup layak untuk digunakan sebagai area pembudidaya ikan, baik itu dilihat dari kualitas air yang mendukung kehidupan ikan budidaya, pertumbuhan ikan yang dibudidayakan, serta aman tidaknya ikan hasil budidaya itu untuk dikonsumsi manusia dilihat dari kandungan logam beratnya.

\section{METODE PENELITIAN}

\section{Lokasi}

Percobaan dilakukan di kolam pengendap DS 2 (posisi: 196000 mN dan 94000 mE) terletak di Sengatta, Kabupaten Kutai Timur Provinsi Kalimantan Timur dengan iklim tropika basah, seluas 9,4 ha dan kedalaman terdalam adalah sekitar $15 \mathrm{~m}$. Kolam ini memiliki outlet sebanyak 1 buah dan inlet 4 buah. Kolam merupakan kolam yang sebelumnya dipakai untuk mengendapkan dan memperlakukan air (penambahan kapur dolomite untuk menaikkan $\mathrm{pH}$ serta kaporit untuk penjernihan) yang masuk sebagai aliran dan air dari tambang sebelum dibuang ke Sungai Sangatta yang berjarak sekitar $100 \mathrm{~m}$ dari kolam, tetapi sekitar tahun 2003 lalu sudah tidak terpakai lagi dan masih menjadi tanggungjawab PT KPC dalam pengelolaannya. Sebelum percobaan ini dimulai, telah dilakukan penelitian kualitas air dan jenis-jenis ikan yang hidup alami di danau ini. Kualitas air selama 30 hari yang diukur tiap jam di kolam pengendap pada kedalaman $50 \mathrm{~cm}$ dari permukaan air diperoleh hasil (rata-rata atau $\mu \pm$ simpangan baku atau Sd) adalah untuk suhu: $28,35 \pm 0,23^{\circ} \mathrm{C}$; oksigen terlarut atau DO: 5,69 $\pm 0,22 \mathrm{mg} / \mathrm{L}$; kekeruhan: 446,08 $\pm 8,46$ NTU; pH: 7,37 \pm 0,05; Daya Hantar Listrik: $20,48 \pm 0,16 \mu \mathrm{S} / \mathrm{m}$; dan total padatan terlarut atau TDS: $130 \pm 0 \mathrm{mg} / \mathrm{L}$, yang apabila dibandingkan dengan persyaratan budidaya ikan menurut Wedemeyer (1996) dengan $\mathrm{pH}$ : 6,0-9,0; DO: >4 mg/L, dan kekeruhan: <20 NTU. 
Konsentrasi oksigen terlarut dan $\mathrm{pH}$ di kolam pengendap ini masih cukup mendukung kehidupan ikan yang akan dibudidayakan.

\section{Wadah Pemeliharaan}

Wadah pemeliharaan menggunakan keramba ukuran $3 \mathrm{~m} \times 1 \mathrm{~m} \times 1 \mathrm{~m}$ terbuat dari jaring aluminium untuk antenna parabola sebagai lapisan terluar, dan waring atau net hitam di lapisan dalam, dengan kerangka dari balok kayu ulin (Eusideroxylon zwageri T. et B.) ukuran penampang $5 \mathrm{~cm} \times 5 \mathrm{~cm}$. Keramba menggunakan bahan terluar dari kawat untuk parabola ini dapat menekan harga keramba hingga $20 \%$ lebih murah jika dibandingkan dengan lapisan terluar bilah kayu ulin seluruhnya, dan sangat berguna pada wilayah yang banyak terdapat predator biawak. Keramba diapungkan setinggi $40 \mathrm{~cm}$ dari permukaan air (bagian yang tenggelam adalah sekitar $60 \mathrm{~cm}$ ) dengan menggunakan drum plastic sebanyak 4 buah untuk tiap keramba.

\section{Benih Ikan}

Benih ikan repang (Barbodes schwanenfeldii) ukuran rata-rata 20,2 g dan puyau (Osteichilus kappenii) ukuran 66,1 g diperoleh dari pengumpul di wilayah hulu Sungai Mahakam. Sedangkan ikan mas (Cyprinus carpio) ukuran 28,96 g dari pemijahan di-breeding unit di Universitas Mulawarman. Ikan repang, puyau, dan mas ditebar sebanyak masingmasing 200 ekor untuk tiap-tiap keramba ( 67 ekor $/ \mathrm{m}^{2}$ ). Sedangkan pepuyu (Anabas testudineus) ukuran rata-rata $41,4 \mathrm{~g}$ diperoleh dari pengumpul setempat. Udang galah (Macrobrachium rosenbergii) ukuran 113,8 g juga dari alam diperoleh dari pengumpul. Udang galah dan pepuyu ditebar dengan kepadatan 50 ekor per keramba ( 17 ekor/ $\mathrm{m}^{2}$ ). Dalam pengangkutannya, benih ditaruh dalam kantongan plastik yang ditambahkan oksigen, dan dikemas dalam kotak sterofoam yang telah ditambahkan juga batu es untuk mendinginkan selama pengangkutan benih dari lokasi pengumpulan hingga ke lokasi keramba.

\section{Pakan}

Percobaan ini menggunakan pelet apung untuk ikan mas, puyau, dan repang. Sedangkan untuk udang galah digunakan pelet untuk udang windu. Pelet buatan pabrik ini memiliki kandungan protein minimal 35\%. Untuk pepuyu diberi pakan dedak. Pemberian pakan di- lakukan ad lib. (sampai kenyang) diberikan pukul 07.00 pagi dan pukul 16.00 sore.

\section{Pengukuran Kualitas Air dan Pertumbuhan Ikan}

Pengukuran parameter kualitas air: suhu $\left({ }^{\circ} \mathrm{C}\right)$, oksigen terlarut atau DO $(\mathrm{mg} / \mathrm{L})$, kekeruhan (NTU), pH, Daya Hantar Listrik $(\mu \mathrm{S} / \mathrm{m})$, dan total padatan terlarut atau TDS ( $\mathrm{mg} / \mathrm{L}$ ) diukur menggunakan Horiba DX20 di air dalam keramba dan di luar keramba dengan frekuensi 3 x sehari (pagi, siang, dan sore) selama 4 bulan pemeliharaan. Sedangkan pertumbuhan bobot total ikan diukur tiap bulan dengan menyampling secara acak sebanyak 5 ekor tiap jenisnya. Logam tidak diukur pada parameter kualitas air, dikarenakan dari komunikasi pribadi dengan pengelola kualitas air kolam PT KPC kandungan logam berat adalah tidak terdeteksi, dan dari Hall et al. (1997) diketahui pula bahwa logam berat air raksa $(\mathrm{Hg})$ dalam bentuk yang toksik yaitu methyl merkuri, terkandung dalam tubuh ikan melalui jalur rantai makanan daripada langsung melalui difusi pada insang.

\section{Pengukuran Logam Berat pada Daging Ikan}

Sampel ikan dan udang diambil sebanyak masing-masing 2 ekor yaitu pada udang galah, repang, puyau, dan ikan mas. Selain itu, diambil juga sampel ikan yang hidup liar di kolam ini sebanyak 2 ekor tiap jenis, yaitu: ikan gabus (Channa striata), sepat siam (Trichogaster pectoralis), udang galah (M. rosenbergii), dan puyau (O. kappenii). Sampel ini diperiksa kandungan logam di dalam hati atau daging untuk ikan, dan hanya daging untuk udang galah. Ikan sampel dibawa ke laboratorium dalam keadaan rantai dingin (dalam cool box bersuhu $-4^{\circ} \mathrm{C}$ ), dan diambil daging atau hati dengan menggunakan alat bedah sebanyak 1 gram. Sampel selanjutnya dikeringkan di dalam oven listrik, diukur kadar air, dan selanjutnya didestruksi menggunakan asam nitrat pekat. Aliquot selanjutnya diperiksa kandungan logamnya dengan menggunakan Atomic Absorption Spectrophotometer (AAS) merek Shimadzu. Hasil pengukuran dinyatakan dalam $\mathrm{mg} / \mathrm{kg}(\mathrm{mg} / \mathrm{L})$ bobot basah, dan rasio terdeteksinya dihitung dengan rumus:

Rasio terdeteksi $=$ (Frekuensi sampel yang positif mengandung logam / Total sampel yang diperiksa) $\times 100 \%$ 


\section{HASIL DAN BAHASAN}

\section{Pertumbuhan Bobot Ikan}

Hasil penelitian menunjukkan bahwa bekas kolam pengendap tambang batu bara cukup layak untuk dikembangkan sebagai areal budidaya ikan dengan memberikan pertumbuhan bobot ikan repang dengan bobot awal rata-rata $28,2 \mathrm{~g}$ menjadi rata-rata $135,5 \mathrm{~g}$ selama 4 bulan pemeliharaan, atau terjadi pertumbuhan sebesar $570,79 \%$. Demikian pula dengan puyau berbobot awal rata-rata $66,1 \mathrm{~g}$ menjadi $200 \mathrm{~g}$ (tumbuh sebesar $202,57 \%$ ), mas dari bobot awal rata-rata 28,96 menjadi 194,9 g (573\%), udang galah dari bobot rata-rata $113,8 \mathrm{~g}$ menjadi $360,7 \mathrm{~g}(238,92 \%)$, dan pepuyu dari bobot rata-rata $41,4 \mathrm{~g}$ menjadi $225,5 \mathrm{~g}(447,10 \%)$. Tidak semua ikan yang dipelihara memiliki survival rate (SR) yang tinggi melebihi $95 \%$ seperti pada repang (SR: 95\%) ataupun pada ikan puyau (SR: 97\%), tiga jenis ikan lainnya yaitu mas, udang galah, dan pepuyu masing-masing hanya memiliki survival rate sebesar: $2,5 \%, 10 \%$, dan $14 \%$. Kematian yang tinggi pada ketiga jenis organisme di atas kelihatannya disebabkan oleh penyebab yang berbeda pula. Ikan mas yang dipelihara pada percobaan ini merupakan benih hasil dari pemijahan buatan di unit breeding yang suhunya stabil berkisar $25^{\circ} \mathrm{C}$ (data tidak dipublikasikan), sehingga kemungkinan mengalami stres dan berakhir kematian akibat perubahan suhu di lokasi pemeliharaan yang tercatat berkisar $27^{\circ} \mathrm{C}-32^{\circ} \mathrm{C}$ (Gambar 2) dengan fluktuasi yang cukup besar dalam seharinya (Gambar 2).

\section{Kualitas Air Selama Penelitian}

\section{Suhu air}

Wedemeyer (1996) menyatakan bahwa suhu air baru akan memberikan akibat stres pada ikan yang dibudidayakan apabila suhu naik atau turun melebihi $10^{\circ} \mathrm{C}$. Tetapi dari penelitian Lima et al. (2006) dengan memberikan perlakuan perbedaan suhu air: $24^{\circ} \mathrm{C}$, $27^{\circ} \mathrm{C}$, dan $30^{\circ} \mathrm{C}$ pada ikan air tawar surubim (Pseudoplatystoma sp.) diperoleh hasil bahwa suhu $27^{\circ} \mathrm{C}$ memberikan pertumbuhan yang optimal dibanding suhu $30^{\circ} \mathrm{C}$ yang justru menyebabkan terjadinya stres dan lebih rendahnya survival rate dari perlakuan lainnya. Kecenderungan dari dampak suhu terhadap ikan mas dapat dilihat juga dari perubahan tingkah lakunya, yaitu ikan yang semula muncul di permukaan air saat mengambil

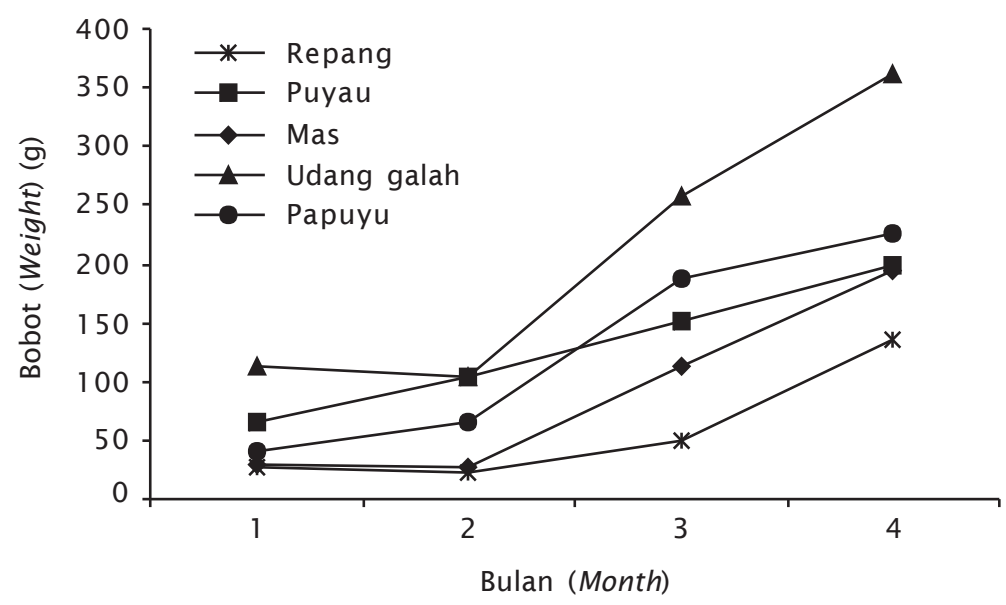

Gambar 1. Pertumbuhan ikan dan udang di dalam keramba selama 4 bulan pemeliharaan. Semua hewan kultur menunjukkan pertambahan bobot, walaupun tidak diiringi dengan tingkat sintasan untuk udang galah, mas, dan pepuyu

Figure 1. The trend of fish and shrimp growth in the fish cages after 4 months of rearing period. All of the cultured organisms showed increased weight except survival rate for giant prawn, common carp, and climbing pearch 


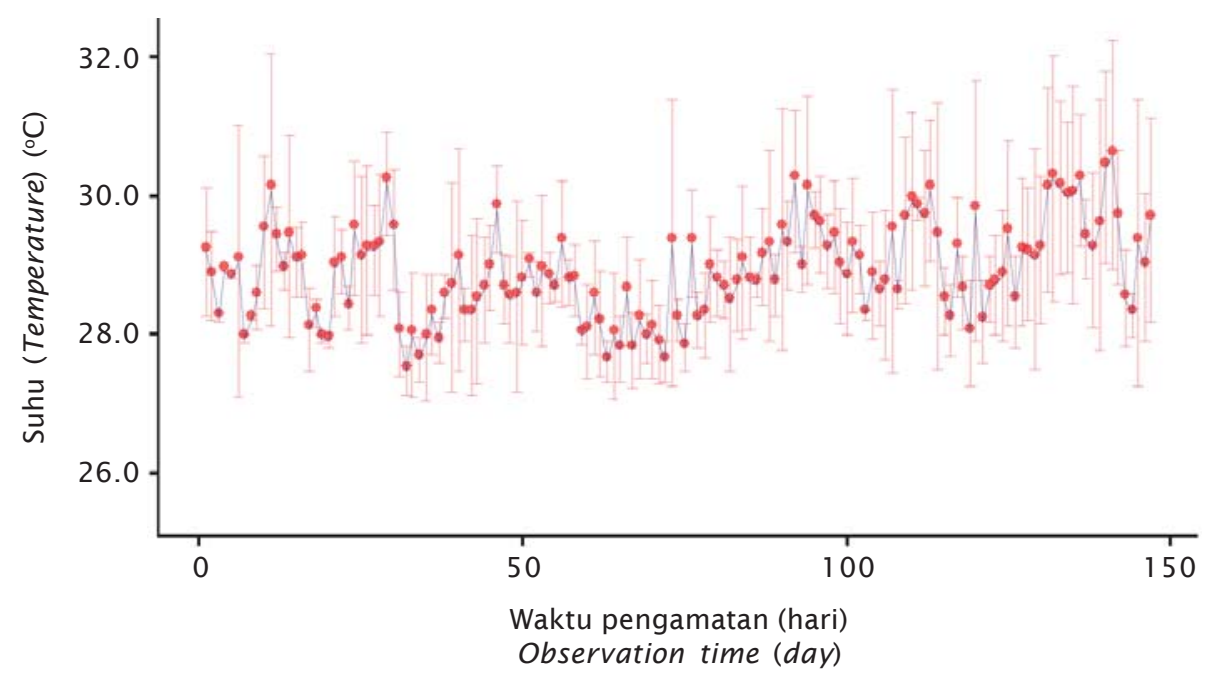

Gambar2. Fluktuasi suhu rata-rata selama percobaan (garis merah menunjukkan simpangan baku, sedangkan garis biru menunjukkan nilai rata-rata)

Figure 2. Fluctuation of water temperature presented in mean value (the red line is standard deviation, while the blue is mean value)

pakan, tetapi setelah beberapa hari sejak tebar kemudian berubah hanya berdiam di dasar keramba memakan pakan yang tenggelam, yang kemungkinan suhu air di permukaan adalah lebih panas lagi dibandingkan dengan suhu sekitar dasar keramba yang berkisar $28^{\circ} \mathrm{C}$ (data penelitian pendahuluan). Kami menduga ini berkaitan dengan suhu media, dikarenakan ikan pada umumnya memang akan menghindari wilayah dengan suhu yang dapat membahayakan kehidupannya (Kramer et al., 1997), dan telah diketahui pula ada perubahan tingkah laku ikan akibat perubahan suhu yang telah diteliti oleh Magoulick \& Wilzbach (1998) pada 2 spesies ikan salmon yang memperlihatkan bahwa ikan salmon bertingkah laku kurang agresif dalam berinteraksi interspesies, tetapi pertumbuhannya lebih cepat dan memangsa umpan lebih banyak pada suhu yang lebih dingin. Demikian juga yang terjadi pada udang galah. Udang galah adalah biota air yang hidup di dasar perairan dengan suhu yang relatif stabil, yaitu pada suhu: $24,2 \pm 1,0^{\circ} \mathrm{C}$ (Adhikari et al., 2007), atau pada suhu $25,6 \pm 0,5^{\circ} \mathrm{C}$ (Danaher et al., 2007). Kami menduga, udang galah yang kami pelihara juga mengalami stres dengan suhu yang lebih tinggi dari tempat asalnya, disertai fluktuasi suhu yang mencapai $5^{\circ} \mathrm{C}$. Kanibalisme memang memungkinkan pada udang galah, tetapi untuk kanibalisme, kami telah mengantisipasinya dengan memberikan shelter berupa potongan paralon yang cukup banyak di dalam keramba. Sedangkan untuk ikan pepuyu, kematian kelihatannya berhubungan dengan luka-luka disaat pengangkutan yang dikarenakan ikan ini memiliki tulang sirip yang berujung tajam, serta tutup overculum yang juga berduri tajam.

\section{Kekeruhan}

Pengaruh dari tingginya kekeruhan mungkin terjadi pada penelitian ini, karena pada pengamatan yang dilakukan selama penelitian, kekeruhan adalah sangat tinggi, dengan nilai terendah mencapai 10x lebih besar dari batas tertinggi nilai kekeruhan sebesar 20 NTU (Wedemeyer, 1996). Hasil pengamatan parameter kekeruhan terlihat pada Gambar 3.

Hal ini belum dapat dipastikan dapat membahayakan kehidupan ikan, karena belum ada nilai konsentrasi baku yang jelas untuk kekeruhan perairan di daerah tropis dan hubungannya dengan kehidupan ikan-ikan lokal. Tetapi menurut Boyd (1982), kekeruhan yang disebabkan oleh suspensi partikel liat umumnya sangat tidak diinginkan dalam kegiatan budidaya perairan. Partikel liat yang tersuspensi dapat mengganggu pernapasan telur dalam masa inkubasi, mengganggu 


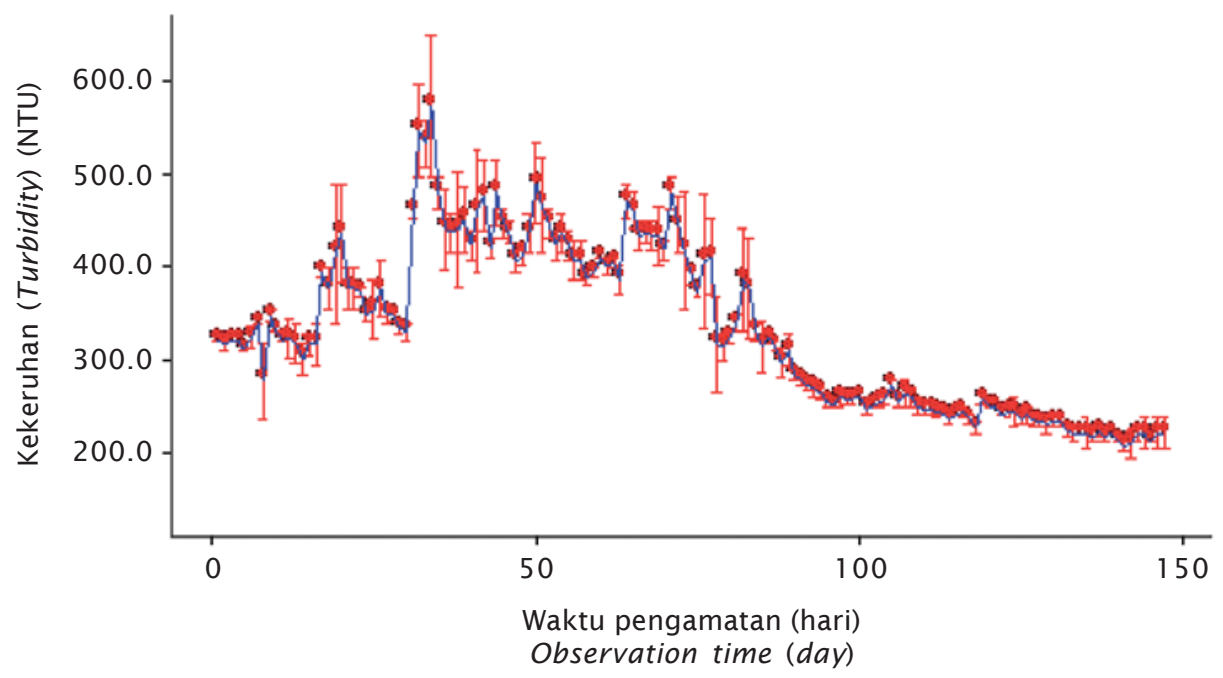

Gambar 3. Hasil pengukuran kekeruhan (NTU) selama penelitian. Garis biru menunjukkan nilai rata-rata, sedangkan garis merah menunjukkan simpangan baku nilai pengamatan

Figure 3. The turbidity values during the experiment period. The red line is mean values, and the blue line is standard deviation

penglihatan ikan saat mencari makan, dan secara fisik menutupi insang ikan sehingga mempersulit pernapasan (Wedemeyer, 1996; Barret et al, 1992; Berg \& Northcote, 1985). Ataupun berdampak sebaliknya, yaitu melindungi spesies ikan tertentu dari pemangsaan (Johnson \& Hines, 1999). Selain berpengaruh secara fisik, tingkah laku ikan juga dipengaruhi oleh kekeruhan. Pada percobaan dengan ikan salmon (brook trout), Sweka \& Hartman (2001) menemukan bahwa reaksi ikan menjadi lamban terhadap kemunculan mangsa seiring dengan meningkatnya kekeruhan. Walaupun kekeruhan sangat mempengaruhi tingkah laku ikan, tetapi jarang sekali kekeruhan yang tinggi hingga berakibat dengan kematian pada ikan (Gradall \& Swenson, 1982). Sehingga kami dalam penelitian ini tidak dapat menyandarkan alasan kematian ikan dalam keramba sebagai akibat dari kekeruhan yang sangat tinggi ini. Sedangkan parameter kualitas air seperti konsentrasi oksigen terlarut (DO), pH, Daya Hantar Listrik (DHL), dan total padatan terlarut (TDS) adalah cukup mendukung.

\section{Kelarutan Oksigen}

Kelarutan oksigen di antara 4-10 mg/L pada media pemeliharaan terlihat pada Gambar 4.
Pada Gambar 4 terlihat bahwa kandungan oksigen di media penelitian menunjukkan kandungan terendah yang cukup tinggi yaitu melebihi $4 \mathrm{mg} / \mathrm{L}$, walaupun dengan perubahan yang cukup besar baik dari jam ke jam, maupun dari hari ke hari selama penelitian.

\section{pH}

Demikian juga pada nilai $\mathrm{pH}$ yang sekitar $6-8,5$. Nilai $\mathrm{pH}$ ini dapat dikatakan optimal dalam mendukung pertumbuhan ikan, dikarenakan secara umum pertumbuhan ikan adalah optimal pada pH 6-9 (Wedemeyer, 1996). Hasil pengamatan $\mathrm{pH}$ perairan dan fluktuasinya selama 150 hari penelitian di keramba diperlihatkan pada Gambar 5.

Pada penelitian ini, sama seperti pada penelitian terdahulu memang tidak dapat menunjukkan adanya pengaruh limbah air asam tambang (acid mining drainage) dikarenakan kolam pengendap DS2 ini telah mengalami pemberian kapur untuk menaikkan $\mathrm{pH}$ air, sehingga $\mathrm{pH}$ air yang tercatat adalah cukup tinggi serta memenuhi persyaratan bagi budidaya ikan. Terkecuali jika terjadi pemberian kapur yang tidak merata, serta masih adanya aliran lemah air bawah tanah ber-pH sekitar 4 yang bisa masuk ke kolam tanpa 


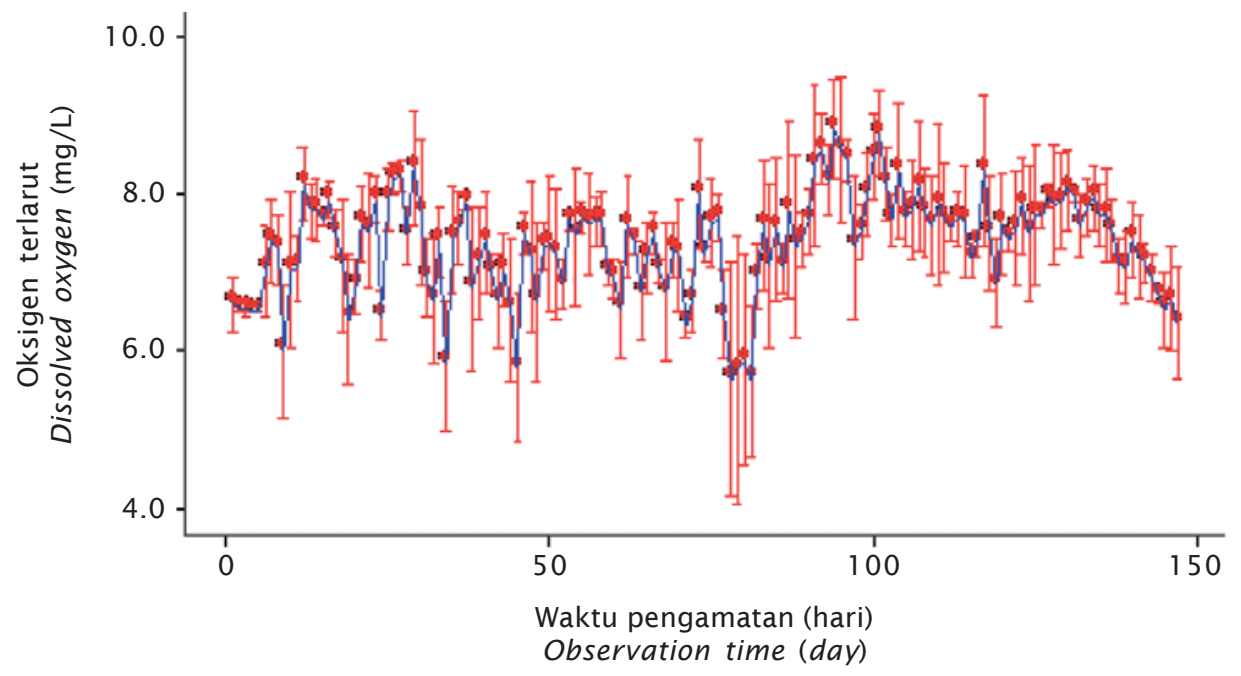

Gambar 4. Nilai rata-rata (garis biru) dan simpangan baku (garis merah) dari kelarutan oksigen (DO) selama penelitian

Figure 4. The mean value of dissolved oxygen concentration is expressed by the blue line, while the standard deviation of the concentration is represented by the red line

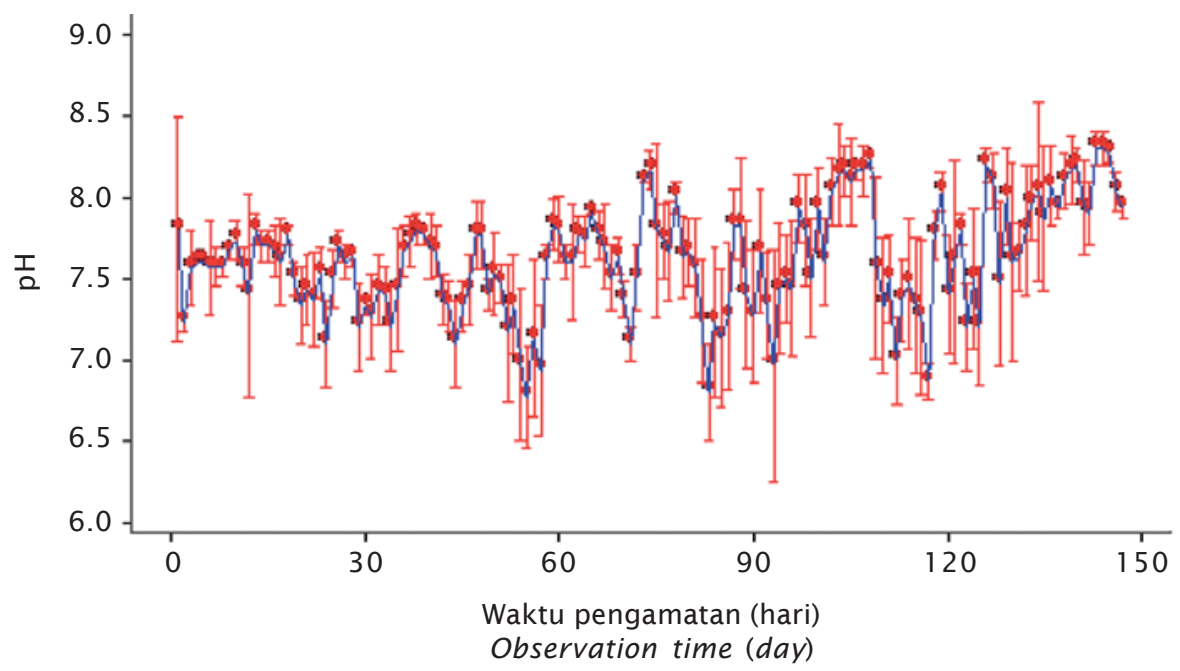

Gambar 5. Nilai rata-rata pH (garis biru) dan simpangan baku nilai hasil pengamatan (garis merah) selama penelitian

Figure 5. The mean values of $\mathrm{pH}$ (blue line) and its standard deviation (red line) during the experiment

terdeteksi, karena hasil penelitian Warren et al. (2005) pada telur ikan salmon menunjukkan kegagalan $100 \%$ untuk menetas pada $\mathrm{pH}$ asam sekitar 4.

\section{Daya Hantar Listrik dan Total Padatan Terlarut}

Kedua nilai pengamatan untuk parameter daya hantar listrik dan total padatan 

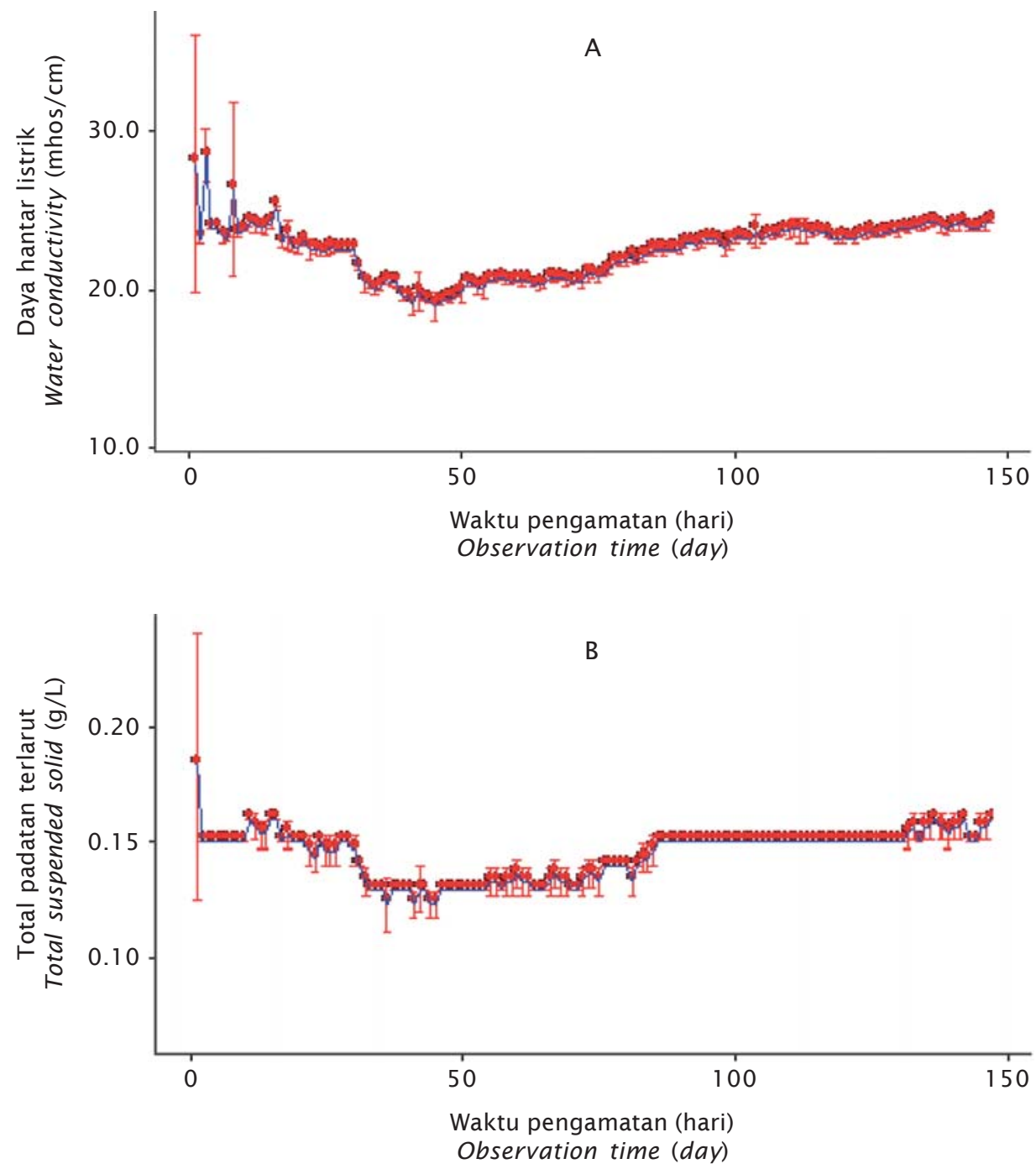

Gambar 6. Hasil pengukuran daya hantar listrik (DHL) dalam mmhos/cm (A), dan total padatan terlarut (TDS) dalam $\mathrm{g} / \mathrm{L}$ (B), garis biru menunjukkan nilai rata-rata pengamatan, sedangkan merah adalah simpangan baku dari nilai pengamatan

Figure 6. The trend of water conductivity variation and total suspended solid was represented in figure $A$ and $B$, the mean value and standar deviation line are represented in blue and red lines respectively

terlarut ditampilkan pada Gambar 6A dan Gambar 6B.

Hasil pengukuran menunjukkan bahwa nilai daya hantar listrik (DHL) dalam penelitian ini masih dalam batas normal. Pada Gambar 6 terlihat bahwa daya hantar listrik (A) dan total padatan terlarut (B) terlihat tidak begitu berfluktuasi dari hari ke hari, dan memiliki pola fluktuasi yang mirip, dikarenakan pada umumnya nilai daya hantar listrik berhubungan erat dengan total padatan terlarut, karena samasama menunjukkan garam-garam yang terlarut di perairan. Menurut APHA (1981), perairan yang umum bisa dipakai untuk kehidupan ikan di Amerika Serikat memiliki nilai daya hantar listrik di antara 50-1500 mhos/cm (5-150 
$\mathrm{mS} / \mathrm{m}$ ) dan nilai total padatan terlarut (TDS) sebaiknya tidak melebihi $200 \mathrm{mg} / \mathrm{L}$ (Wedemeyer, 1996), yang pada penelitian kali ini masih memenuhi baku mutu tersebut.

\section{Hasil Pengukuran Logam Berat}

Hasil pengujian kandungan logam pada ikan dan udang yang dipelihara dan dari tangkapan di alam, serta kemudian membandingkan nilai-nilai yang diperoleh dengan baku mutu berdasarkan Pengawasan Obat dan Makanan (POM) Indonesia dan Food and Drug Agency (FDA) Amerika Serikat, diperoleh hasil: $\mathrm{Sb}(0,24-2,45 \mathrm{mg} / \mathrm{L}$, rasio terdeteksi dari sampel: $100 \%$, belum ada baku mutu), Se (0,00-0,06, 57, 14\%, tidak ada baku mutu), As (tidak terdeteksi/ttd, POM: 1 mg/L, FDA: 78-86 $\mathrm{mg} / \mathrm{L}), \mathrm{Hg}(0,00-0,06 \mathrm{mg} / \mathrm{L}, 50 \%, \mathrm{POM}: 0,5$, FDA: 1,0 ), Mn (ttd-1,68 mg/L, 14,29\%, tidak ada baku mutu), Cd (ttd, POM: 1 mg/L, 3-4 mg/L), Fe (ttd-5,45 mg/L, 7,14\%, tidak ada baku mutu), $\mathrm{Cu}$ (ttd, POM: $20 \mathrm{mg} / \mathrm{L}$ ), Pb (ttd, POM: 2, FDA: 1,5-1,7 mg/L), dan Zn (7,82-61,50 mg/L, 100\%, POM: $100 \mathrm{mg} / \mathrm{L})$. Logam Hg terdeteksi dari pengukuran ini dengan konsentrasi jauh di bawah baku mutu yang diperbolehkan dan rasio terdeteksi adalah 50\%. Tetapi dengan mengingat bahwa: konsentrasi logam berbeda untuk tiap individu dan spesies ikan, jumlah ikan yang dikonsumsi manusia tidaklah besar dan berasal dari berbagai lokasi, kebiasaan makan ikan yang tidak sama tiap individu, serta sistem osmoregulasi pada tubuh manusia terhadap zat-zat berbahaya (Agency for Toxic Substances \& Disease Registry/ATSDR, 2003), maka dapat disimpulkan bahwa ikan-ikan hasil budidaya dan ikan-ikan liar di kolam pengendap tambang batu bara ini adalah cukup layak dan aman untuk dikonsumsi.

\section{KESIMPULAN DAN SARAN}

Dari hasil penelitian ini dapat disimpulkan bahwa usaha budidaya ikan dapat dikembangkan pada kolam-kolam bekas tambang batubara yang kualitas airnya telah dikelola sebelumnya, dengan jenis-jenis ikan lokal seperti repang (B. schwanenfeldii), puyau ( $O$. kappenii), pepuyu (A. testudineus), dan udang galah (M. rosenbergii), ataupun ikan introduksi yaitu ikan mas (C. carpio). Ikan-ikan produk dari kolam tambang batubara ini cukup aman untuk dikonsumsi.

Pada pemeliharaan dengan benih dari luar lokasi, patut sekali diperhatikan perbedaan suhu ataupun kualitas air lainnya, serta sistem pengangkutan terbaik untuk mencegah stres pada benih, agar tingkat sintasan dapat terjaga baik.

\section{UCAPAN TERIMA KASIH}

Kami mengucapkan terima kasih yang sebesar-besarnya kepada pihak PT KPC yang telah memberikan bantuan dalam penyediaan lokasi penelitian dan berbagai fasilitas lainnya. Ucapan terima kasih kami sampaikan kepada Fakultas Perikanan dan IImu KelautanUniversitas Mulawarman, Dinas Kelautan dan Perikanan Kabupaten Kutai Timur dalam pemberian izin untuk melakukan penelitian ini. Ucapan terima kasih juga kepada Pak H. Saleh yang telah menyediakan benih ikan lokal, serta rekan-rekan mahasiswa: Yudho Wahyu Bekti Utomo, Agus Tri H., M. Rusdiansyah, dan Sarifudin yang telah melakukan pengelolaan keramba penelitian.

\section{DAFTAR ACUAN}

Abdel-Tawwab, M. \& Wafeek, M. 2010. Response of Nile tilapia, Oreochromis niloticus (L.) to environmental cadmium toxicity during organic selenium supplementation. Journal of the Aquaculture Society, 41: 106114.

Adhikari, S., Naqvi, A.A., Pani, K.C., Pillai, B.R., Jena, J.K., \& Sarangi, N. 2007. Effect of manganese and iron on growth and feeding of juvenile giant river prawn, Macrobrachium rosenbergii (De-Man). Journal of World Aquaculture Society, 38: 161-168.

Agency for Toxic Substance and Disease Registry (ATSDR). 2003. Public health assessment: Fish and shellfish evaluation Isla De Vieques bombing range Vieques, Puerto Rico.Http://www.atsdr.cdc.gov/sites/ vieques/vieques.html. Dikunjungi: Juni 2010.

APHA. 1981. Standard methods for the examination of water and wastewater. American Public Health Association, Washington D.C., $1,130 \mathrm{pp}$.

Barret, J.G., Grosman, G..D., \& Rosenfeld, J. 1992. Turbidity induced changes in reactive distance of rainbow trout. Transaction of the American Fisheries Society, 121:437443.

Berg, L. \& Northcote, T.G. 1985. Changes interritorial, gill-flaring, and feeding 
behavior in juvenile coho salmon (Onchorynchus kisutch) following short term pulses of suspended sediment. Canadian Journal of Fisheries and Aquatic Sciences, 42: 1,410-1,417.

Boyd, C.E. 1982. Hydrology of small experimental fish pond at Auburn, Alabama. Transaction of the American Fisheries Society, 111 : 638-644.

Danaher, Tidwell, J.J.J.H., Coyle, S.H., Dasgupta, S., \& Zimba, P.V. 2007. Effect of two densities of caged mono sex nile tilapia, Oreochromis niloticus, on water quality, phytoplankton populations, and production when polycultured with Macrobrachium rosenbergii in temperate ponds. Journal of the World Aquaculture Society, 38: 367382.

Farag, A.M., Woodward, D.F., Brumbaugh, W., Goldstein, J.N., MacConnell, E., Hogstrand, C., \& Barrows, F.T. 1999. Dietary effect of metals-contaminated invertebrates from the Coeur d'Alene River, Idaho, on cutthroat trout. Transaction of the American Fisheries Society, 128: 578-592.

Fiss, F.C. \& Carline, R...F. 1993. Survival of brook trout embryos in three episodically acidified streams. Transactions of American Fisheries Society, 122: 268-278.

Goddard, C.I., Leonard, N.J., Stang, D.L., Wingate, P.J., Rattner, B.A., Franson, J.C. \& Sheffield, S.R. 2008. Management concern about known and potential impact of lead use in shooting and in fishing activities. Fisheries, 33: 228-236.

Gorski, P.R., Lathrop, R.C., Hill, S.D., \& Herrin, R.T. 1999. Temporal mercury dynamic and diet composition in the mimic shiner. Transactions of American Fisheries Society, 128: 701-712.

Gradall, K.S. \& Swenson, W.A. 1982. Responses of brook trout and creek chubs to turbidity. Transactions of American Fisheries Society, 111:392-395.

Grippo, R.S. \& Dunson, W.A. 1996. The body ion loss biomarker. 1. Interactions between trace metals and low $\mathrm{pH}$ in reconstituted coal mine-polluted water. Environmental Toxicology and Chemistry, 15: 1,9551,963 .

Hall, B.D., Bodfaly, R.A., Fudge, R.J.P., Rudd, J.W.M., \& Rosenberg, D.M. 1997. Food as dominant pathway of methylmercury uptake by fish. Water, Air, and Soil Pollution, 100: 12-24.
Hanten, Jr.R.P., Neumann, R.M., Wartd, S.M., Carley, R.J., Perkins, C.R., \& Pirrie, R. 1998. Relationship between concentration of mercury in largemouth bass and physical and chemical characteristics of Connecticut Lakes. Transaction of the American Fisheries Society, 127: 807-818.

Heinen, J.M. 1996. Water quality criteria, uptake, bioaccumulation and public health considerations for chemicals of possible concern in West Virginia mine waters used for culture of rainbow trout. The Conservation Fund's Freshwater Institute, Shepardstown, $42 \mathrm{pp}$.

Hermann, R. \& Baumgartner, I. 1992. Aluminum species distribution during mixing of acid coal and slate mine drainage with neutral stream waters. Geologische Rundschau, 81: 759-767.

Ingersoll, C.G., Mount, D.R., Gulley, D.D., La Point, T.W., \& Bergman, H.L. 1990. Effect of $\mathrm{pH}$, aluminum, and calcium on survival and growth of eggs and fry of brook trout Salvelinus fontinalis. Canadian Journal of Fisheries and Aquatic Sciences, 47: 1,5801,592 .

Johnson, J.E. \& R.T. Hines. 1999. Effect of suspended sediment on vulnerability of young razorback suckers to predation. Transactions of the American Fisheries Society, 128: 648-655.

Kramer, D.L., Rangeley, R.W., \& Chapman, L.J. 1997. Habitat selection: pattern of spatial distribution from behavioral decisions. In Behavioural Ecology of Fishes (Godin, Jeann-Guy. J. Ed.). Blackwell, New York, p. 37-80.

Lachance, S., Bérubé, P., \& Lemieux, M. 2000. In situ survival and growth of three brook trout (Salvelinus fontinalis) strains subjected to acid conditions of anthropogenic origin at the egg and fingerling stages. Canadian Journal of Fisheries and Aquatic Sciences, 57: 1,562-1,573.

Lima, L.S., Ribeiro, L.P., Malison, J.A., Barry, T.P., \& Held, J.A. 2006. Effect of temperature on performance characteristics and the cortisol stress response of surubim Pseudoplatystoma sp. Journal of the World Aquaculture Society, 37: 89-95.

Magoulick, D.D. \& Wilzbach, M.A. 1998. Effect of temperature and macrohabitat on interspecific aggression, foraging success, and growth of brook trout and rainbow trout pairs in laboratory streams. Transactions 
of the American Fisheries Society, 127: 707-717.

McNevin, A.A. \& Boyd, C.E. 2004. Copper concentrations in channel catfish Ictalurus punctatus pond treated with copper sulfate. Journal of the World Aquaculture Society, 35: 16-24.

Miller, D.J., Semmens, K.J., Viadero Jr., R.C., \& Tierney, A.E. 2004. The resource potential of mining discharge water for aquaculture. World Aquaculture, 35: 57-59.

Salam, A., Ansari, T.M., Tariq, N., \& Akhtar, Q.A. 2002. Effect of body size on metal concentrations in farmed Cirrhinus mrigala. Asian Fisheries Science, 15: 329-334.

Saiki, M.K., Castleberry, D.T., May, T.W., Martin, B.A., \& Bullard, F.N. 1995. Copper, cadmium, and zinc concentrations in aquatic food chains from the upper Sacramento River (California) and selected tributaries. Archives of Environmental Contamination and Toxicology, 26: 484-491.

Short, T.M., Black, J.A., \& Birge, W.J. 1990. Effect of acid-mine drainage on the chemical and biological character of an alkaline headwater stream. Archives of Environmental Contamination and Toxicology, 19: 241248.

Silva, E.I.L. \& Shimizu, A. 2004. Concentration of trace metals in the flesh of nine species found in a hydropower reservoir. Asian Fisheries Science, 17: 377-384.

Simmons, J.A., Summerfelt, S., \& Lawrence, M. 2001. Mine water aquaculture: A West Virginia, USA success story. Global Aquaculture Advocate, 4: 57-59.

Stafford, C.P., Hansen, B., \& Stanford, J.A. 2004. Mercury in fishes and their diet items from Flathead Lake, Montana. Transactions of the American Fisheries Society, 133: 349357.

Sweka, J.A. \& Hartman, K.J. 2001. Influence of turbidity on brook trout reactive distance and foraging success. Transaction of the American Fisheries Society, 130: 138-146.

Van Breemen, N. 1973. Dissolved aluminum in acid sulfate soils and acid mine waters. Proceeding of the American Soil Society, 37: 694-697.

Warren, D.R., Sebestyen, S.D., Josephson, D.C., Lepak, J.M., \& C.E. Kraft. 2005. Acidic groundwater discharge and in situ egg survival in redds of lake-spawning brook trout. Transactions of American Fisheries Society, 134: 1,193-1,201.

Wedemayer, G..A. 1996. Physiology of fish in intensive culture systems. Chapman \& Hall, New York, 232 pp. 